\title{
Host plant specificity and feeding preferences of Morpho epistrophus argentinus (Lepidoptera: Nymphalidae) larvae in coastal woodlands of Argentina
}

\author{
Especificidad de la planta hospedadora y preferencia alimentaria \\ de larvas de Morpho epistrophus argentinus (Lepidoptera: \\ Nymphalidae) en bosques costeros de Argentina
}

\begin{abstract}
Mariana E. Carro ${ }^{*}$, Mariela V. Lacoretz², M. Cecilia de Mársico², Gustavo J. Fernández ${ }^{1}$

1 Grupo de Investigación en Ecofisiología de Fauna Silvestre (GIEFAS), CCT Patagonia Norte-CONICET, Asentamiento Universitario San Martín de los Andes (AUSMA), Universidad Nacional del Comahue, Pje de la Paz 235, (8370) San Martín de los Andes, Neuquén, Argentina.

2 Departamento de Ecología, Genética y Evolución-IEGEBA CONICET, Facultad de Ciencias Exactas y Naturales. Universidad de Buenos Aires, Ciudad Universitaria, (1428) Ciudad Autónoma de Buenos Aires, Argentina.

* Email: mcarro.ausma@gmail.com
\end{abstract}

\begin{abstract}
The selection of suitable host plants for larval development is critical for most herbivorous insects. In this study, we examined host plant preferences of larvae from Epistrophus white morpho butterfly, Morpho epistrophus argentinus (H. Fruhstorfer), a specialized butterfly that oviposits on a few plant species. In many species, the selection of host plant for larvae development is under the control of ovipositing females and the role of larvae in host selection is minimal. At field, we characterized larval host plant use in coastal woodland patches of its southernmost distribution range ( $36^{\circ} 25^{\prime} \mathrm{S}, 56^{\circ} 57^{\prime} \mathrm{W}$; Argentina). All sampled M.e. argentinus larvae groups $(\mathrm{n}=40)$ were found on Scutia buxifolia trees, although the number of larval groups did not correlate with cover of this plant at patch scale. Translocation experiments showed that M.e. argentinus larvae translocated to unsuitable host plants had a shorter residence time than those translocated to suitable (i.e. control) hosts. Choice assays

Ref. bibliográfica: Carro, M. E.; Lacoretz, M. V.; de Mársico, C.; Fernández, G. J. 2019. “Host plant specificity and feeding preferences of Morpho epistrophus argentinus (Lepidoptera: Nymphalidae) larvae in coastal woodlands of Argentina". Acta zoológica lilloana 63 (1): 1-13. Fundación Miguel Lillo, Tucumán, Argentina. D.O.I.: https://doi.org/10.30550/j.azl/2019.63.1/1

> Recibido: 15/05/19 - Aceptado: 31/05/19

> URL de la revista: http://actazoologica.lillo.org.ar

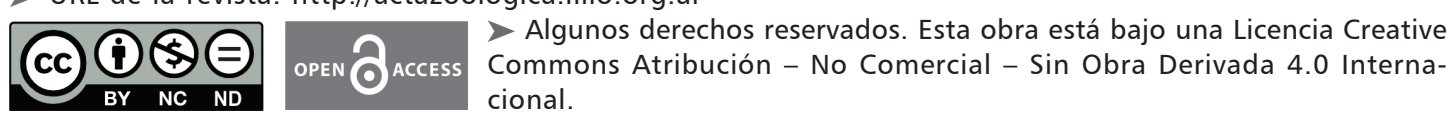


made also indicated strong feeding preferences of wild larvae for S. buxifolia leaves. The results highlight the high degree of host specificity of M.e. argentinus by $S$. buxifolia, and reveal that growing larvae preference for host plant matches that of ovipositing females.

Palabras clave - Butterfly, host plant selection, larval behavior, larval preferences.

\section{RESUMEN}

La selección de plantas hospedadoras adecuadas para el desarrollo larvario es crítica para la mayoría de los insectos herbívoros. En este estudio, examinamos las preferencias de la planta hospedadora de larvas de la mariposa Bandera Argentina, Morpho epistrophus argentinus (H. Fruhstorfer), una mariposa especializada que ovipone en pocas especies de plantas. En muchas especies, la selección de plantas hospedadoras para el desarrollo de las larvas está bajo el control de las hembras y el papel de las larvas en la selección de hospedadores es mínimo. En el campo, caracterizamos el uso de la planta hospedadora por parte de las larvas en parcelas de bosques costeros de su área de distribución más meridional $\left(36^{\circ} 25^{\prime} \mathrm{S}, 56^{\circ} 57^{\prime} \mathrm{W}\right.$; Argentina). Todos los grupos de larvas de M.e. argentinus muestreados $(\mathrm{n}=40)$ fueron encontrados en árboles de la especie Scutia buxifolia, aunque el número de grupos de larvas no se correlacionó con la cobertura de esta planta a escala de parche. Experimentos de translocación demostraron que las larvas de M.e. argentinus translocadas a plantas hospedadoras inadecuadas tuvieron un tiempo de residencia más corto que las translocadas a hospedadores adecuados (i.e. controles). Ensayos de elección realizados también indicaron fuertes preferencias de alimentación de las larvas por hojas de S. buxifolia. Los resultados resaltan el alto grado de especificidad de M.e. argentinus por el hospedador $S$. buxifolia y revelan que la preferencia de las larvas por la planta hospedadora coincide con la de las hembras cuando oviponen.

Keywords - Mariposa, selección de planta hospedadora, comportamiento de las larvas, preferencias de la larva.

\section{INTRODUCTION}

In plant feeding insects, the selection of suitable plants for neonate larvae development is critical as it affects their growth rates and ultimately, their fitness. It has been proposed that females of these species should choose hosts where larval performance is optimal («mother knows best» principle; Thompson, 1988). Accordingly, in many species, the selection of host plant species for larvae development is under the control of ovipositing females (Wiklund, 1975; Futuyma, 1990; Thompson and Pellmyr, 1991; Nylin and Janz, 1993; Price, 2003; Gripenberg et al., 2010). In such species, the role of larvae in host selection is minimal and usually constrained by the difficulty of larvae to move across plants (Prager et al., 2014). In the other extreme, ovipositing females of some species play a minor role in host plant selection, and 
larvae must be able to find suitable hosts for their development (Chew, 1977; Bernays and Chapman, 1994; Berdegué et al., 1998, Crespo and Castelo, 2008).

Many butterfly species have a wider range of suitable host plants for larval development than that they actually use for oviposition (Thompson and Pellmyr, 1991). This reflects mother's preferences and it would be the result of females maximizing their own performance rather than seeking to improve offspring development and survival with their choices (Mayhew, 1997; Prager et al., 2014). In this scenario, larvae may be restricted in host plant use by its mother's preference, and their performance will depend on selection of high-quality hosts by its mother. However, larvae may not be entirely dependent on female's decisions. In some butterfly species, oviposition is not selective with respect to host plant, and larvae must to locate the suitable host (Wiklund, 1984). Then, larval host selection can act as a reinforcing (or correcting) mechanism of maternal host choice, through which immature offspring can circumvent eventual female's oviposition errors (Gamberalle-Stille et al., 2014). In fact, it has been found in the comma butterfly (Polygonia c-album Linnaeus) that larvae can show similar host preference than ovipositing females (Nylin and Janz, 1996; Nylin, Bergström and Janz, 2000; Gamberalle-Stille et al., 2014). Therefore, host-plant choice is not necessarily restricted to female or larvae decisions, and can imply hierarchical mechanisms where both female and larvae decisions are involved.

In this study, we examined preferences of the butterfly larvae Morpho epistrophus argentinus (H. Fruhstorfer) for host plant, in coastal woodlands of central-east Argentina. This conspicuous and specialized Morpho butterfly oviposits on a few plant species (Ackery, 1988; Canals, 2000; Beccaloni et al., 2008). The larvae feed on plant where they hatch, but Orlandi (2016) found that larvae of Morpho epistrophus can be feed with other plant species than those where they were collected. At our study site in the southernmost distribution range of M.e. argentinus, females laid eggs on only one tree species, Scutia buxifolia (Rosales:Rhamnaceae). However, female choice of this perennial tree species may be restricted because the offspring that overwinter in the stage, need protection and shelter, and therefore, may not reflect the larval preferences. In that sense, S. buxifolia is the most abundant perennial native species in the southernmost distribution of the butterfly. However, in the last decades, native woodlands at this range have been severely reduced which threaten the biota that depend on this habitat type (Goya et al., 1992; Arturi and Goya, 2004). Therefore, considering that M.e. argentinus is at risk due to habitat loss, determine the ability of larvae to use alternative host-plant species is important for conservation purposes. Then, our objectives were to characterize plant use by larvae and to assess their host plant preferences using both a translocation experiment and feeding choice assays. We expected that if larvae preferences match those of ovipositing females, they must to prefer to stay on S. buxifolia trees and feed on their leaves avoiding unusual host plants as substrate and food. 


\section{MATERIALS AND METHODS}

\section{Species studied}

Morpho epistrophus argentinus is a big and conspicuous nymphalid butterfly (wingspan: $90-110 \mathrm{~mm}$ ) that inhabits riparian and xerophytic forests along North and East Argentina. The conservation status of this species has not been evaluated yet, but at their southernmost distribution range it is considered as threatened due to the degradation and loss of suitable habitat (Nuñez-Bustos, 2009). At this range, adults are seen flying between late January and March (Gallardo, 1908; Nosswitz, 1927). The females lay small eggs ( $\sim 2 \mathrm{~mm}$ diameter) under the leaves of specific plant species such as $S$. buxifolia, Lonchocarpus nitidus (Fabales: Fabaceae) and Inga vera (Fabales: Fabaceae) (Gallardo, 1907; Canals, 2000; Nuñez Bustos, 2009). At the southernmost distribution range of $M$. e. argentinus, only $S$. buxifolia is present. Larvae emerge after about two weeks, remaining on the host plant (Bourquín, 1944). They do not eat and stay on diapauses gregariously over winter months (Gallardo, 1908; Otero and Marigo, 1990). During September, they resume feeding activity. After first molt, the larvae exhibit an intense reddish color that presumably makes them highly aposematic (García et al., 2014). They rest gregariously during daylight hours, forming clusters of up to 30 individuals. Feeding occurs mostly during night when the cluster breaks up (Turner, 1936). Larvae reach a size of 55-70 $\mathrm{mm}$ at the final instars (Bourquín, 1944). Early in summer (December-January), the larvae migrate from their host plants and pupate.

\section{Field methods}

From October to early December 2015 (austral spring), we searched for larvae clusters at woodland patches at General Lavalle ( $\left.36^{\circ} 25^{\prime} \mathrm{S}, 56^{\circ} 57^{\prime} \mathrm{W}\right)$, Buenos Aires province, Argentina. The site comprises patches of deciduous woodland of Celtis ehrenbergiana and $S$. buxifolia, with a mean vegetation height $<5 \mathrm{~m}$, surrounded by pastures (Lacoretz, 2018).

We quantified host-plant specificity through field observations and censuses. We searched for larvae clusters at 10 randomly selected woodland patches in which the preferred host plant (S. buxifolia) of M.e. argentinus larvae was absent and at other 10 patches where the host plant was present. We surveyed the patches using a $4 \mathrm{x} 40$ $\mathrm{m}$ strip transect, walking through them and carefully searching for M.e. argentinus larvae. Once localized, we identified the host plant species and counted the number of larvae in the cluster. For each larvae cluster, we measured the body length (nearest $2 \mathrm{~mm}$ ) from four arbitrarily selected larvae. Body length was used to estimate the instar to which each group belonged following Orlandin (2016).

We also estimated species cover in each of the 20 woodland patches using eight randomly located sampling points within a $20 \mathrm{~m}$ radius area from the starting point of the strip transect. At each point, a sampling rod (7 m height) marked off in $1 \mathrm{~m}$ intervals was held vertically on the ground and the plant species contacting the rod 
were recorded. Cover for each plant species was estimated as the percentage of sampling points at each woodland patch where the species was present (i.e. contacted the rod).

In one woodland patch, we also searched for M.e. argentinus larvae within a plot of $50 \times 50 \mathrm{~m}$, and when localized, we marked the location of the cluster with a colored and numbered tape for cluster identification. These larval groups ( $\mathrm{n}=$ 12) were revisited after 30 days to note the permanence in the site where they were first found.

\section{Host plant specificity experiments}

To determine host specificity of M.e. argentinus under field conditions, we performed experimental translocations in groups of larvae during late November. Twenty larvae groups were removed from host plants where they were found, and moved to trees located more than $30 \mathrm{~m}$ apart. Ten randomly selected of these groups were placed on branches of $S$. buxifolia (its natural host plant), and the other 10 groups on branches of $C$. ehrenbergiana. The latter is the dominant deciduous tree in the woodlands and thus broadly available for consumption by larvae. Larval size of these groups ranged from 35 to $45 \mathrm{~mm}$ (presumably corresponding to $3^{\text {rd }}-4^{\text {th }}$ instars) and group size was 8-19 individuals. We monitored these groups every 3-4 days up to 17 days after the beginning of the experiment. On each visit, we recorded the number of larvae present at each group and inspected neighbor trees to detect missing individuals or groups.

\section{Feeding preferences}

We also tested the feeding preferences of M.e. argentinus larvae using a choice assay at our field station. We collected 20 individuals (40-52 $\mathrm{mm}$ in length; presumably $4^{\text {th }}$ instar) from 5 larvae clusters (4 individuals/group) at evening hours (18:00-20:00 h) during November. Each larva was placed individually on a plastic box (approximately $15 \times 25 \times 10 \mathrm{~cm}$ ) with the bottom covered with a filter paper slightly moistened with a few drops of water. Boxes were closed with perforated lids and kept in the shade under natural photoperiods and environmental temperatures. After collection, caterpillars were deprived of food for about $12 \mathrm{~h}$. Then we offered leaves of the two most common tree species at our study area to individual larva. Five $1 \times 1 \mathrm{~cm}$ pieces of fresh $S$. buxifolia leaves and 5 of $C$. ehrenbergiana leaves were arranged alternately along the edges of the boxes. Trials started at 8:00 hs. After 12 $\mathrm{h}$, we collected the remaining leaf pieces from each box and estimated the individual consumption of each species as the number of quarters of eaten leaf pieces. Then, the assay was replicated to estimate nocturnal consumption. After the $24 \mathrm{~h}$ trial, 10 of these larvae were returned to their original clusters in the field and the remaining 10 individuals were subjected to a second experiment. At this, the larvae were kept in boxes and were induced to feed only on green leaves of $C$. ehrenbergiana during 3 
consecutive days. After this period, a choice experiment as described above was conducted during night hours. After testing, the larvae were returned to their original field locations. No larval mortality was recorded during the experiments.

\section{Data analyses}

We used descriptive statistics to quantify host plant specificity and the characteristics of plant hosts. The occurrence of M.e. argentinus larvae in woodland patches where S. buxifolia plants was present and absent was compared using a Fisher's exact test. Relationship between the number and size of larvae and the size of group were assessed using Spearman rank correlations. We used a Cox proportional hazard mixed regression model to analyze the results of the translocation experiment. The model included the residence time, defined as the number of visits in which larvae were seen at the translocation site, as the response variable, host plant treatment as a fixed factor and larvae group identity as a random variable. Analysis was performed using the COXME package, v2.7.1 (Therneau, 2015) in the R environment (v3.3.0, $\mathrm{R}$ Core Team, 2016). Feeding preferences of M.e. argentinus larvae were tested using generalized linear mixed models (GLMM) with a Poisson structure and a log-link function. We performed these analyses using the lme4 package, v1.1-17 (Bates et al., 2015) for R. First, we tested for differences in leaf consumption of each tree species by individuals recently collected from the field. For this model, the response variable was the number of leaf quarters consumed, and time of day (day or night), plant species and the interaction term as predictors. Individual identity was included as a random variable. In a second analysis, we compared the feeding preferences of individuals before and after being induced to feed on C. ehrenbergiana. The model included sampling time (before or after induction) and plant species as predictors, and larvae identity as a random factor. The interaction was not assessed because no larval feeding was detected on C. ehrenbergiana before the induction treatment. For all these models, we used residual and normal probability plots to check model assumptions. We assessed the global contribution of predictors to the response variables by comparing the deviance of nested models (i.e., with and without the factor) using likelihood-ratio tests.

We report means with \pm SE for all data (unless otherwise specified). All tests are two-tailed, and differences were considered significant at $P<0.05$.

\section{RESULTS}

The occurrence of M.e. argentinus larvae was strongly related to the presence of $S$. buxifolia plants in the woodland patches (Fisher's exact test, $P<0.01$ ). Morpho epistrophus argentinus larvae were recorded in seven out of 10 woodland patches with $S$. buxifolia, but in none of 10 patches where $S$. buxifolia was absent. Sampled woodland patches were mostly dominated by $C$. ehrenbergiana (mean cover percentage: $58.7 \%$; SD: $30.1 \%$ ). In woodland patches with presence of S. buxifolia, its mean 


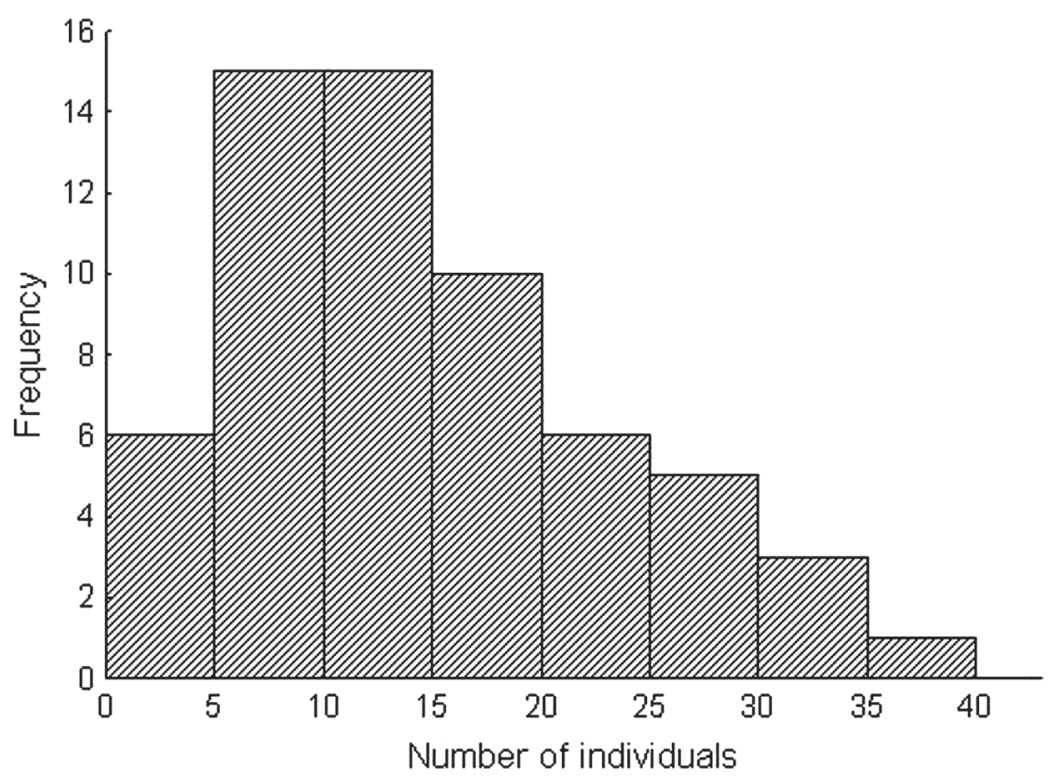

Figure 1 Frequency of group sizes of $M$. e. argentinus larvae $(n=40)$. Larval body size varied from 15 to $35 \mathrm{~mm}$ in length ( $1^{\text {st }}-3^{\text {rd }}$ instars).

cover was $56.7 \%$ (SD: $22.1 \%$ ) and was co-dominant with C. ehrenbergiana (mean cover percentage of this last species: $42.5 \%$; SD: 27.8). Other tree species (e.g., Schinus longifolius, Fodina rhombifolia) had a vegetation cover of less than $5 \%$ at the studied patches.

We found a total of 40 larvae groups, all located on branches of $S$. buxifolia. Larval size of groups recorded varied between 15 and $34 \mathrm{~mm}$, corresponding to $1^{\text {st }}$ $3^{\text {rd }}$ instars. Larvae size was not related to group size (Spearman rank correlation, $R$ $=0.07, P=0.79$ ), and the number of larval groups was not related to $S$. buxifolia cover at patch scale (Spearman rank correlation, $R=0.19, P=0.59$ ). Furthermore, surveyed larvae groups at the $50 \times 50 \mathrm{~m}$ plot $(\mathrm{n}=12)$ remained in the same branches where first observed after 30 days.

\section{Host plant specificity experiments}

From the 10 larvae groups translocated to $C$. ehrenbergiana, only one remained on this host plant after 17 days. Three other larvae groups migrated to neighbor $S$. buxifolia trees and the remaining six were missing. The $C$. ehrenbergiana plant which the larvae group remained showed slight signs of herbivory on its leaves. In contrast, nine of the larvae groups translocated to $S$. buxifolia branches remained in their new location. Only one group was missing and it was not observed in the neighboring trees. As expected, residence time was significantly lower for individuals translocated to $C$. ehrenbergiana than to $S$. buxifolia trees (Cox regression model: $\chi^{2}{ }_{1}=16.77, P$ $<0.01$; Fig. 2). 


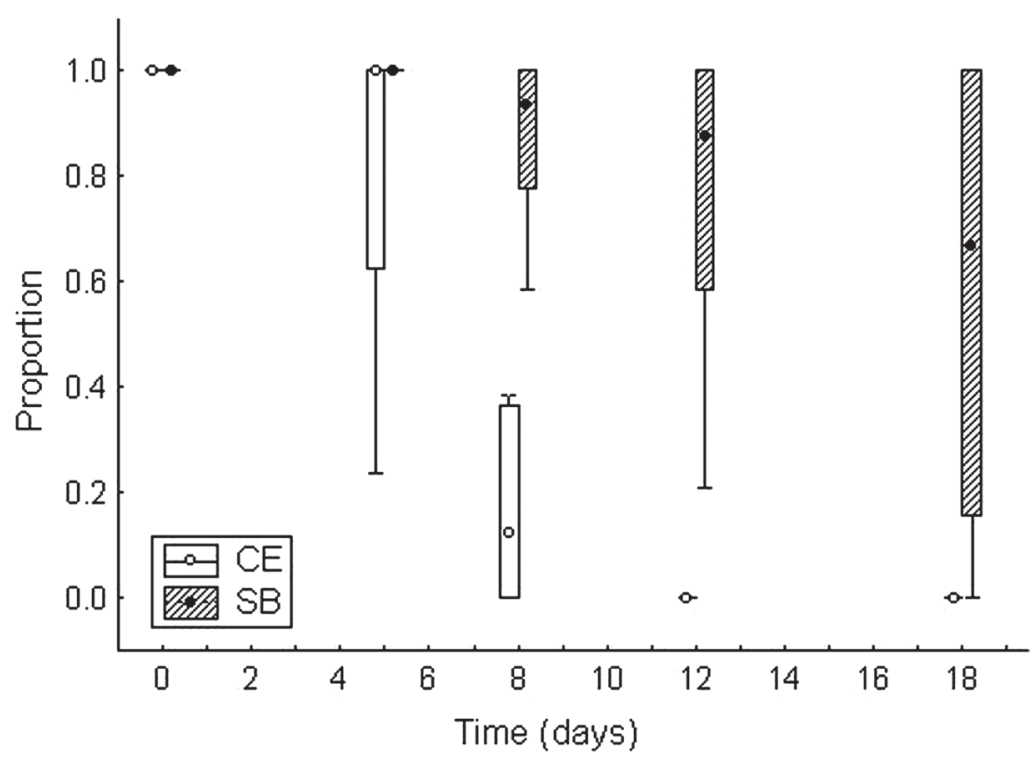

Figure 2 Proportion of M.e. argentinus larvae that remained in clusters translocated to $C$. ehrenbergiana ( $C E ; n=10$; white boxes) and $S$. buxifolia trees $(S B ; n=10$; sptriped boxes) along the experiment. Median (dots), interquartil range (boxes) and minimum and maximum values (whiskers) values are shown.

\section{Feeding preferences}

The choice experiment showed a marked preference of $M$. .e. argentinus for feeding upon $S$. buxifolia leaves $\left(\chi^{2}{ }_{1}=305.47, P<0.01\right.$; Fig. 3a). Larval feeding activity was highest during the night $\left(\chi^{2}{ }_{1}=19.20, P<0.01\right.$; Fig. 3a), but preferences did not change with the time of day (interaction term: $\chi^{2}{ }_{1}=0.17, P=0.68$ ). Although the larvae increased slightly the consumption of $C$. ehrenbergiana leaves after being induced to feed on this host plant (Fig. 3b), they fed preferentially on $S$. buxifolia leaves both before and after that treatment (plant species: $\chi^{2}{ }_{1}=208.31, P<0.01$, sampling time: $\chi^{2}{ }_{1}=0.28, P=0.59$; Fig. $3 b$ ).

\section{DISCUSSION}

It is widely accepted that herbivorous insects should prefer host plant species that will maximize their fitness. This concept can be expanded to include the selection of oviposition sites, as females should choose those host plants that are optimal for the development of their offspring (Thompson, 1988; Valladares and Lawton, 1991; Scheirs et al., 2000; Gripenberg et al., 2010). Morpho epistrophus argentinus oviposits on a few plant species (Ackery, 1988; Canals, 2000; Beccaloni et al., 2008) and, in its southernmost distribution range, it uses exclusively S. buxifolia for oviposition. Consistent with this, all larvae groups in this study were found attached to branches of $S$. buxifolia, in woodland patches that had this tree as a codominant species. Conversely, we could not find $M$. e. argentinus larvae in patches were $S$. buxifolia was absent. These observations suggest a high degree of specializa- 

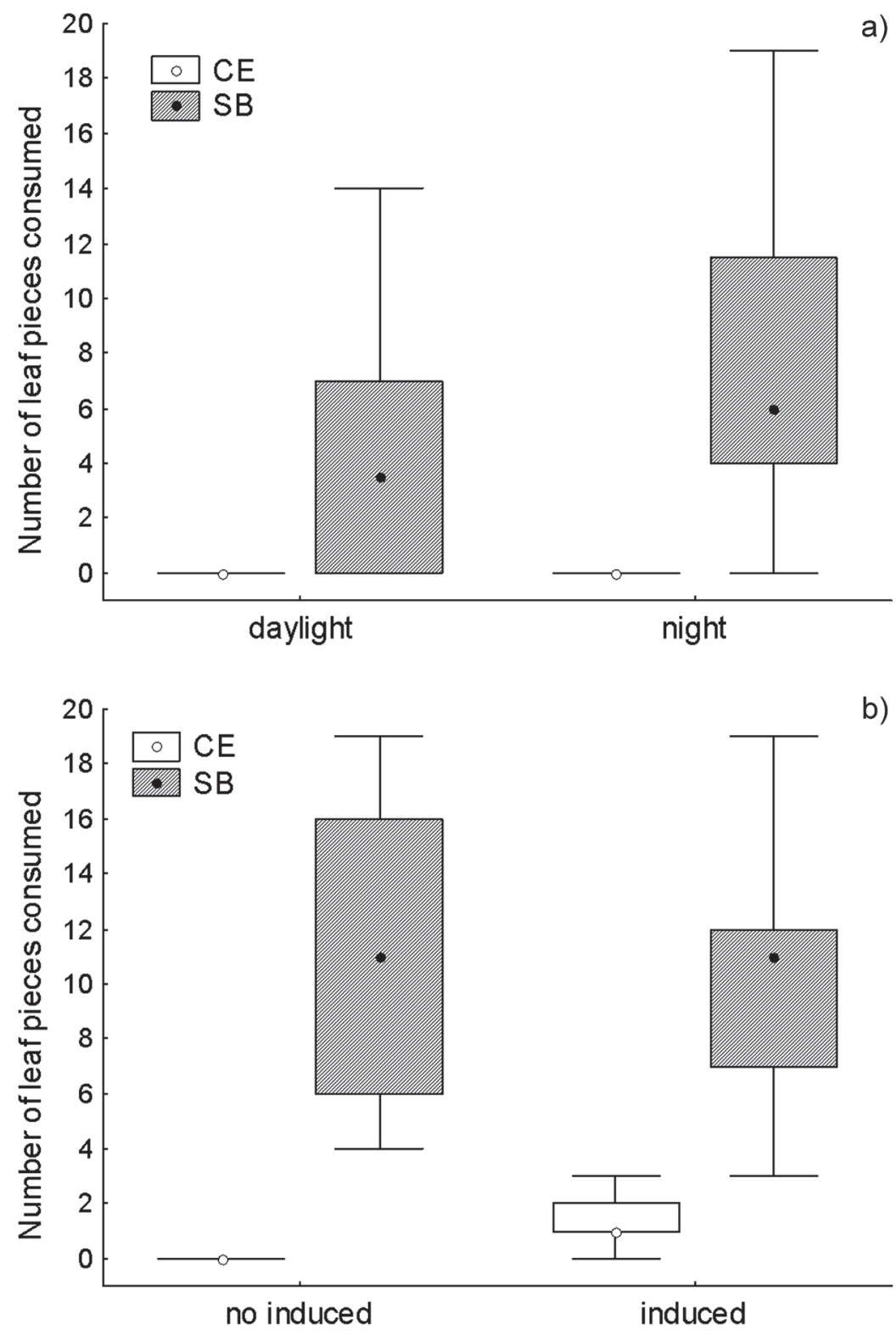

Figure 3 Consumption of C. ehrenbergiana (CE; white boxes) and S. buxifolia (SB; grey boxes) leaves by wild M.e. argentinus larvae in choice assays. a) Leaf consumption of each plant species during daytime and night time ( $n=20$ larvae). b) Leaf consumption of each plant species of individual larvae before and after being induced to feed on $C$. ehrenbergiana leaves for three days $(n=20)$. Medians (dots), interquartile ranges (boxes) and minimum and maximum values (whiskers) are shown.

tion in host plant use, although the causes of such specificity are not known yet. It is possible that $S$. buxifolia provides larvae with crucial nutrient components or secondary compounds that maximize their growth and survival. Alternatively, this plant species could provide better habitat quality for offspring that begin to emerge at the end of the summer and overwinter as larvae. S. buxifolia is the main evergreen species present at our study area, and therefore, it can provide refuge and food for M.e. argentinus throughout the larval stage.

Our experiments also demonstrate that larvae of M.e. argentinus have a strong preference for settling and feeding on S. buxifolia. Most of the caterpillar's groups 
translocated to C. ehrenbergiana abandoned this host plant within a week. We observed that three of these larvae moved to nearby $S$. buxifolia trees, indicating that larvae are able to switch among host plants, at least after achieving a certain degree of development. This host-switching ability of mobile larvae might allow them to reduce fitness costs associated to adverse development conditions.

Feeding experiments further confirm this apparent larval preference for $S$. buxifolia. Wild caterpillars showed strong preferences for $S$. buxifolia leaves in choice assays, even after being induced for $48 \mathrm{~h}$ to feed upon an alternative host plant. It is possible that such induction period was insufficient to change larval preferences, but it has been observed that feeding preferences can change even after shorter periods (Jermy et al., 1968). The results suggest that host-plant preferences of M.e. argentinus larvae could be innate or acquired through imprinting in early life stages (Jermy et al., 1968; Yamamoto, 1974; Jermy, 1987; Bernays and Weiss, 1996; Silva, Gonçalves and Moreira, 2014; Rosenwald et al., 2017). The observed preferences could reflect larval constraints in host selection if larvae are influenced by mother choice at early stages rather than active host choice. The mechanisms underlying host selection in this species deserves further investigation. For example, additional cross-fostering experiments of newly hatched larvae could help to understand how host plant preferences develop in M.e. argentinus.

In sum, our results show that larval preferences for host plants were highly species-specific and match those of ovipositing females in M.e. argentinus. From a conservationist perspective, such host-plant species specificity implies that actions to secure the status of this butterfly must rely on local ecological information and should be focused on habitat and host-plant preservation. Therefore, considering that native woodlands have suffered a strong reduction at the southernmost distribution range, the persistence of M.e. argentinus in this region will depend on the efforts made for the conservation of the remaining native woodland areas.

\section{ACKNOWLEDGMENTS}

We thank Luis García for allowing us to work on his ranch in Buenos Aires, and Martha Busai, Mario Beade and their families for logistical support. We also thank Dr. Mariano Ordano for useful comments and suggestions and two anonymous reviewers who revised an earlier version of the manuscript. All methods used in the present study meet the ethical requirements for science research and comply with the current laws of the country in which they were performed.

\section{FUNDING}

This research did not receive any specific grant from funding agencies in the public, commercial, or not-for-profit sectors. This study and protocols we used were approved by the Organización Provincial para el Desarrollo Sustentable (OPDS) from Buenos Aires province, Argentina (Disp. 019/15). 


\section{ETHICAL STATEMENT}

No larva died or was physically damaged as a consequence of our experimental procedures. During manipulations, we handled the individuals carefully to remove them from the field and to return them to their original locations after the experiments.

\section{PARTICIPATION}

MEC, MVL, MCDM and GJF planed and designed the study; MVL and MCDM performed field censuses; GJF performed translocation experiments and field observations; MEC executed feeding preferences experiments; MEC and GJF performed all data analyses; MEC, MCDM and GJF wrote the manuscript.

\section{CONFLICTS OF INTEREST}

The authors declare that there is no conflict of interest.

\section{LITERATURE CITED}

Ackery P. R. (1988). Host plants and classification: a review of nymphalid butterflies. Biological Journal of the Linnean Society, 33, 95-203.

Arturi, M. F., Goya, J. F. (2004). Estructura, dinámica y manejo de los talares del NE de Buenos Aires. In: Arturi M. F., Frangi J. L., Goya, J.F. (eds), Ecología y manejo de los bosques de Argentina (1-24). Editorial de la Universidad Nacional de La Plata, La Plata, Argentina.

Bates, D., Maechler, M., Bolker, B., Walker, S. (2015). Fitting linear mixed-effects models using lme4. Journal of Statistical Software, 67, 1-48.

Berdegué, M., Reitz, S. R., Trumble, J. T. (1998). Host plant selection and development in Spodoptera exigua: do mother and offspring know best? Entomologia Experimentalis et Applicata, 189, 57-64.

Bernays, E. A., Chapman, R. F. (1994). Host-plant selection by phytophagous insects. London: Chapman and Hall.

Bernays, E. A., Weiss, M. R. (1996) Induced food preferences in caterpillars: the need to identify mechanisms. Entomologia Experimentalis et Applicata, 78, 1-8.

Beccaloni, G. W., Viloria, A. L., Hall, S. K., Robinson, G. S. (2008) Catalogue of the hostplants of the Neotropical butterflies. Zaragoza: Sociedad Entomológica Aragonesa.

Bourquín, F. (1944). Mariposas argentinas: vida, desarrollo, costumbres y hechos curiosos de algunos lepidópteros argentinos. Buenos Aires: El Ateneo.

Canals, G. R. (2000). Mariposas bonaerenses. Buenos Aires: Editorial LOLA. 
Chew, F. S. (1977). Coevolution of pierid butterflies and their Cruciferous food plants. 2. Distribution of eggs on potential food plants. Evolution, 31, 568-579.

Crespo, J. E., Castelo, M. K. (2008). The ontogeny of host-seeking behaviour in a parasitoid dipteran. Journal of Insect Physiology, 54, 842-847.

Futuyma, D. J. (1990). Observations on the taxonomy and natural history of Ophraella Wilcox (Coleoptera: Chrysomelidae), with a description of a new species. Journal of the New York Entomological Society, 98, 163-186.

Gallardo, A. (1907). Observaciones sobre la metamorfosis de Morpho catenarius (Perry) en los alrededores de Buenos Aires. Anales de la Sociedad Científica Argentina, $63,52-57$.

Gallardo, A. (1908). Invernada de las orugas de Morpho catenarius (Perry). Anales de la Sociedad Científica Argentina, 64, 200-203.

Gamberalle-Stille, G., Söderlind, L., Janz, N., Nylin, S. (2014). Host plant choice in the comma butterfly-larval choosiness may ameliorate effects of indiscriminate oviposition. Insect Science, 21, 499-506.

García, C. R., Gallusser, S., Lachaume, L., Blandin, P. (2014). The ecology and life cycle of the Amazonian Morpho cisseis phanodemus Hewitson, 1869, with a comparative review of early stages in the genus Morpho (Lepidoptera: Nymphalidae: Morphinae). Tropical Lepidoptera Research, 24, 67-80.

Goya, J. F., Placci, G., Arturi, M. F., Brown, A. (1992). Distribución y características estructurales de los talares de la reserva de biosfera «Parque Costero del Sur». Revista de la Facultad de Agronomía de La Plata, 68, 53-64.

Gripenberg, S., Mayhew, P. J., Pamell, M., Roslin, T. (2010). A meta-analysis of preference-performance relationships in phytophagous insects. Ecology Letters, 13, 383-393.

Jermy, T. (1987). The role of experience in the host selection of phytophagous insects. In: Chapman, R. F., Bernays, E. A., Stoffolano, J. G. (eds), Perspectives in chemoreception and behavior (143-157). New York: Springer-Verlag.

Jermy, T., Hanson, F. E., Dethier, V. G. (1968). Induction of specific food preference in lepidopterous larvae. Entomologia Experimentalis et Applicata 11, 211-230.

Lacoretz, M. V. (2018). Análisis de la estructura del ensamble de aves de los montes de tala (Celtis ehrenbergiana) del este de la provincia de Buenos Aires. PhD thesis, University of Buenos Aires.

Mayhew, P. J. (1997). Adaptive patterns of host-plant selection by phytophagous insects. Oikos, 79, 417-428.

Nosswitz, F. (1927). Biología de Morpho argentinus Fruhst. Revista de la Sociedad Entomológica Argentina, 5, 13-15.

Núñez Bustos, E. O. (2009). La fauna de mariposas (Insecta: Lepidoptera) del Parque Costero del Sur (Partidos de Magdalena y Punta Indio, provincia de Buenos Aires, Argentina). In: Athor, J. (ed), Parque Costero del Sur: Magdalena y Punta Indio (278-294). Buenos Aires: Fundación de Historia Natural Félix de Azara.

Nylin, S., Bergström, A., Janz, N. (2000). Butterfly host plant choice in the face of possible confusion. Journal of Insect Behavior, 13, 469-482. 
Nylin, S., Janz, N. (1993). Oviposition preference and larval performance in Polygonia c-album (Lepidoptera: Nymphalidae): the choice between bad and worse. Ecological Entomology, 18, 394-398.

Nylin, S., Janz, N. (1996). Host plant preferences in the comma butterfly (Polygonia c-album): do parents and offspring agree? Ecoscience, 3, 285-289.

Orlandin, E. (2016). Observações sobre a biologia de algumas espécies de Nymphalidae. In: Orlandin, E., Favretto, M. A., Piovesan, M., dos Santos, E. B. (eds), Borboletas e Mariposas de Santa Catarina: uma introdução. Campos Novos: MA Favretto.

Otero, L. S., Marigo, L. M. (1990). Borboletas. Beleza e comportamento de espécies brasileiras. Rio de Janeiro: Marigo Comunicação Visual.

Prager, S. M., Esquivel, I., Trumble, J. T. (2014). Factors influencing host plant choice and larval performance in Bactericera cockerelli. PLoS ONE, 9, e94047.

Price, P. W. (2003). Macroevolutionary theory on macroecological patterns. Cambridge: Cambridge University Press.

R Development Core Team (2016). R: A language and environment for statistical computing. Vienna: RFoundation for Statistical Computing. http://www. Rproject.org/

Rosenwald, L. C., Lill, J. T., Lind, E. M., Weiss, M. R. (2017). Dynamics of host plant selection and host-switching by silver-spotted skipper caterpillars. Arthropod-Plant Interactions, 11, 833-842.

Scheirs, J., De Bruyn, L., Verhagen, R. (2000). Optimization of adult performance determines host choice in a grass miner. Proceedings of the Royal Society of London B, 267, 2065-2069.

Silva, A. K., Gonçalves, G. L., Moreira, G. R. P. (2014). Larval feeding choices in heliconians: Induced preferences are not constrained by performance and host plant phylogeny. Animal Behaviour, 89, 155-162.

Therneau, T. (2015). Mixed effects Cox models. URL: https://cran.r-project.org/web/ packages/coxme/vignettes/coxme.pdf. Accessed March 23, 2018.

Thompson, J. N. (1988). Mini-review: Evolutionary ecology of the relationship between oviposition preference and performance of offspring in phytophagous insects. Entomologia Experimentalis et Applicata, 47, 3-14.

Thompson, J. N., Pellmyr, O. (1991). Evolution of oviposition behavior and host preference in Lepidoptera. Annual Review of Entomology, 36, 65-89.

Turner, H. J. (1936). Further extracts from a S. American correspondent - Morpho catenarius. Entomologist's Record, 48, 114-115.

Valladares, G., Lawton, J. (1991). Host-Plant selection in the holly leaf-miner: Does mother know best? Journal of Animal Ecology, 60, 227-240.

Wiklund, C. (1975). Evolutionary relationship between adult oviposition preferences and larval host plant range in Papilio machaon L. Oecologia, 18, 185-197.

Wiklund, C. (1984). Egg-laying patterns in butterflies in relation to their phenology and the visual apparency and abundance of their host plants. Oecologia, 63, 23-29.

Yamamoto, R. T. (1974). Induction of hostplant specificity in the tobacco hornworm, Manduca sexta. Journal of Insect Physiology, 20, 641-650. 